\title{
ANALISIS KEBUTUHAN UNTUK BERWIRAUSAHA PADA SISWA BERKEBUTUHAN KHUSUS
}

\author{
Edi Purwanta, Hermanto, Sukinah, dan Farida Harahap \\ Fakultas Ilmu Pendidikan Universitas Negeri Yogyakarta \\ Email: edi_purwanta@uny.ac.id,
}

\begin{abstract}
Abstrak: Berwirausaha adalah salah satu alternatif masa depan bagi para penyandang kebutuhan khusus, tetapi belum banyak yang menekuninya. Penelitian ini bertujuan mengidentifikasi kebutuhan ABK untuk berwirausaha. Penelitian dilakukan melalui survei terhadap 37 siswa berkebutuhan khusus yang terdiri atas 19 laki-laki dan 18 perempuan dari 4 SLB di Yogyakarta. Sampel diambil secara purposif, yaitu mereka yang sudah berada di kelas lanjutan. Pengumpulan data menggunakan kuestioner, wawancara, dan skala eksplorasi karier. Hasil penelitian menunjukkan 27 orang belum mantap untuk berwirausaha dan 10 sudah mantap. Eksplorasi karier dan intensitas untuk berwirausaha termasuk dalam kategori sedang. Hambatan terbesar yang dirasakan siswa berkebutuhan khusus ada tiga hal, yaitu kurangnya informasi mengenai lapangan kerja, tidak bisa mengambil keputusan, dan tidak mengenali kemampuan diri. Dari hasil penelitian dapat disimpulkan bahwa siswa berkebutuhan khusus sangat membutuhkan berbagai bantuan untuk meningkatkan motivasi dan minat berwirausaha.
\end{abstract}

Kata Kunci: anak berkebutuhan khusus, kebutuhan berwirausaha

\section{ANALYSIS OF THE NEED OF ENTREPRENEURSHIP OF STUDENTS WITH SPECIAL NEEDS}

\begin{abstract}
Entrepreneurship is one of the possibilities people with special needs can consider for their future, but not many of them have done it. This study aims to identify the needs of students with special needs for entrepreneurship. The study was conducted through a survey to 37 students with special needs, 19 males and 18 females from four SLBs in Yogyakarta. Students of advanced classeswere selected through purposive sampling. Data were collected through questionnaires, interviews, and career exploration scale. The results show that 27 students are not ready and 10 students are ready for doing entrepreneurship. Career exploration and intensity for entrepreneurship can be categorized medium. The biggest obstacles experienced by students with special needs are lack of information about employment, inability in decision making, and inability in self-identification. The results of this study show that students with special needs need various helps for improving their motivation and interest in entrepreneurship.
\end{abstract}

Keywords: children with special needs, needs of entrepreneur (self-employed)

\section{PENDAHULUAN}

Anak berkebutuhan khusus (ABK) atau children with special education need adalah terminologi yang digunakan dalam sistem pendidikan sebagai pengganti istilah anak cacat atau anak luar biasa. Anak berkebutuhan khusus (special needs children) secara sederhana dideskripsikan sebagai anak yang lambat (slow) atau mengalami gangguan (retarded) yang tidak akan pernah berhasil di sekolah sebagaimana anak-anak normal pada umumnya. Banyak istilah yang dipergunakan sebagai variasi dari berkebutuhan khusus, seperti disability, impairment, dan handicaped.
Kementerian Kesehatan RI (2012:47) lewat Susenas tahun 1998, 2000, 2003 dan 2009 menggunakan istilah kecacatan. Kecacatandimaknai sebagi hilangnya atau abnormalitas fungsi atau struktur anatomi, psikologi, dan fisiologi. Susenas 2009 menggunakan istilah disabilitas dan cacat. Disabilitas didefinisikan sebagai ketidakmampuan melaksanakan sesuatu aktivitas atau kegiatan tertentu sebagaimana layaknya orang normal. Cacat adalah kelainan atau kerusakan anggota tubuh dan sebagainya yang menyebabkan keadaannya menjadi kurang sempurna atau abnormal. Susenas 2012 menggunakan istilah disabilitas dengan definisi ketidakmampuan melaksanakan 
suatu aktivitas atau kegiatan tertentu sebagaimana layaknya orang normal yang disebabkan kondisi impairment (kehilangan/ketidakmampuan) yang berhubungan dengan usia dan masyarakat.

Anak berkebutuhan khusus atau ABK adalah anak-anak yang mengalami gangguan (disfungsi) secara fisik,mental/intelektual, sosial, dan emosionalbaik yang bersifat menetap dan seumur hidup (misalnya: anak keterbelakangan mental, tunarungu, tunadaksa, tunanetra, autistik, hiperaktif, cerebral palsy, dan anak dengan gangguan belajar spesifik) atau yang bersifat temporer (misal: anak yang mengalami trauma pasca bencana atau musibah). Dengan segala kekurangannya, mereka seharusnya memunyai kesempatan yang sama untuk memperoleh kehidupanseperti anak-anak normal pada umumnya, yaitu ruanghidup yang layak dan kesempatan yang sama untuk mengoptimalkan potensi yang dimiliki.

Berdasarkan data Susenas tahun 2003 (Kementerian Kesehatan RI, 2012: 67), jumlah anak dengan disabilitas sebanyak 679.048 anak, dimana sebagian besar anak dengan disabilitas $(85,6 \%)$ berada di masyarakat. Hanya sebagian kecil anak dengan disabilitas $(14,4 \%)$ berada di institusi, yaitu sekolah, panti, dan Lembaga Kesejahteraan Sosial Anak (LKSA). Sebagian masyarakat masih menganggap anak dengan disabilitas sebagai aib keluarga sehingga orangtua/keluarga cenderung menyembunyikan dan kurang memperhatikan kebutuhan anak sesuai hak anak, baik di bidang pendidikan maupun kesehatan.

Seharusnya, penyandang cacat merupakan bagian masyarakat Indonesia yang juga memiliki kedudukan, hak, kewajiban dan kesempatan serta peran yang sama dalam segala aspek kehidupan maupun penghidupan seperti halnya warga negara Indonesia yang lain. Kini, pengakuannya telah dikuatkan secara hukum melalui UU No 4 Th 1997 , diikuti terbitnya Peraturan Pemerintah No 43 Th 1998 tentang upaya peningkatan kesejahteraan sosial penyandang cacat.

Undang-undang No. 4 Tahun 1997 menegaskan bahwa penyandang cacat merupakan bagian masyarakat Indonesia yang juga memiliki kedudukan, hak, kewajiban, dan peran yang sama. Pada pasal 6 dijelaskan bahwa setiap penyandang cacat berhak memperoleh: (1) pendidikan pada semua satuan, jalur, jenis, dan jenjang pendidikan; (2) pekerjaan dan penghidupan yang layak sesuai jenis dan derajat kecacatan, pendidikan, dan kemampuannya; (3) perlakuan yang sama untuk berperan dalam pembangunan dan menikmati hasil-hasilnya; (4) aksesibilitas dalam rangka kemandiriannya; (5) rehabilitasi, bantuan sosial, dan pemeliharaan taraf kesejahteraan sosial; dan (6) hak yang sama untuk menumbuhkembangkan bakat, kemampuan, dan kehidupan sosialnya, terutamabagi penyandang cacat anak dalam lingkungan keluarga dan masyarakat.

Bekerja merupakan kebutuhan dasar bagi para penyandang disabilitas. Berdasarkan data yang diperoleh dalam penelitian Rokhim \& Handoyo (2015:5) makna bekerjabagi para pekerja penyandang disabilitas adalah sebagai:(1) eksistensi diri, (2) usaha mengumpulkan modal, (3) untuk beradaptasi dengan lingkungan sosial, (4) penghasil tambahan keluarga, dan (5) sumber penghasilan utama keluarga. Bagi penyandang cacat sendiri, terbitnya perundang-undangan tersebut disambut sangat gembira karena dasar pijakan untuk perbaikan nasib telah ada landasan hukumnya.Peluang untuk mendapatkan kesamaan kesempatan, seperti pendidikan, ketenagakerjaan/ pekerjaan, iklim usaha perlakuan yang sama dalam berbagai aspek kehidupan dan penghidupannya secara resmi telah dijamin oleh undang-undang.

Fakta yang ada, perlakuan terhadap para penyandang kebutuhan khusus masih tidak adil. Khususnya di dunia kerja, para penyandang kebutuhan khusus tidak mudah diterima di tempat kerja yang layak.Hasil Riskesdas tahun 2012 (Kementerian Kesehatan RI, 2012:43) diketahui bahwa prevalensi disabilitas tertinggi adalah pada kelompok orang yang tidak bekerja, yaitu sebesar 14,4\%, kelompok wiraswasta/petani/nelayan/buruh sebanyak 8 dan yang terendah pada kelompok orang yang bekerja sebagai pegawai sebanyak $6 \%$.

Karena susah mencari lapangan kerja, berwirausaha kemudian dilirik sebagai salah satu alternatif masa depan bagi para penyandang kebutuhan khusus (Syamsi, 2010:98; Winasti, 2012:183). Penelitian Winasti (2012:185) menunjukkan bahwa motivasi berwirausaha padapenyandang disabilitas fisik adalah untuk menafkahi keluarga, menjalin hubungandengan orang banyak, menolong penyandang disabilitas fisik agar lebih sejahtera,adanya harga diri, dan keinginan untuk setara dengan individu normal.

Terdapat dua istilah yang sering dipakai mengenai wirausaha, yaitu entrepreneurship yang lebih banyak dipakai dan self employment (Gilkerson \& Paauwe, 2003:84). Bagi penyan- 
dang disabilitas, biasanya istilah yang digunakan adalah self employed yang memunyai pengertian orang-orang yang menjadi pendiri, pemilik dan manajer bisnis di bawah tanggung jawab mereka sendiri yang umumnya berupa kebanyakan perusahaan kecil (Caliendo dkk, 2011:792; Gilkerson \& Paauwe, 2003:89). Perbedaannya dengan entrepreneurship adalah skala usaha enterepreneurship lebih besar, punya pekerja yang dibayar dan tanggung jawab yang besar dan berat. Self employment lebih cocok bagi penyandang disabilitas karena permasalahan dalam berwiraswasta cukup berat. Mekanisme pasar menuntut persaingan yang sangat kompetitif, terbatasnya modal dan pengaruh disabel, faktor masalah produksi dan tenaga kerja, masalah pemasaran, desain, kualitas produk dan mitra kerja sehingga setelah membuka usaha terkadang usaha mereka "berjalan di tempat" (Winasti, 2012:185).

Wirausaha (Self Employment). Ada berbagai istilah asing terkait dengan kewirausahaan. Kata kunci yang digunakan secara umum adalah entrepreneurship. Gilkerson \& Paauwe (2003:87) mengemukaan bahwa enterpreneurship mengacu pada orang yang berpartisipasi di pasar tenaga kerja sebagai own-account workers atau pekerja yang memiliki uangnya sendiri, membayar dirinya sendiri, orang yang bekerja untuk diri mereka sendiri, mungkin tidak mempekerjakan orang lain, atau merujuk pada pemilik usaha yang mempekerjakan orang lain. Bagi siswa berkebutuhan khusus kata kunci terkait dalam pencarian jurnal atau istilah di internet adalah entrepreneurship, small businessdanself-employment, yang dikaitkan dengan disabilitydan impairment (Kitching, 2014:66).

Hal ini berbeda dengan seorang entrepreneur (Kiyosaki, 2001:140).Umumnya seorang entrepreneur sukses memulai karirnya sebagai self employed sehingga inilah yang membuat orang menyamakan pengertian keduanya. Perbedaan mendasar terdapat pada sikap diri seorang entrepreneur yang memunyai visi yang jangka panjang, yaitu membentuk suatu sistem bisnis. Sistem bisnis dibentuk supaya pada saat bisnis/ usahanya itu terus berkembang dan telah mantap, maka usaha/bisnis tersebut dapat terus berjalan tanpa kehadiran si entrepreneur. Sistem bisnis yang baik adalah sistem yang dapat menggantikan si entrepreneur dalam operasional harian bisnis dan paling si entrepreneur hanya perlu mengambil keputusan-keputusan penting saja.
Banyak kalangan yang pesimis apakah para penyandang kebutuhan khusus mampu menjadi wirausaha. Penelitian Boylan \& Burchardt (2003:178) mengidentifikasi persepsi negatif tersebut antara lain: sedikitnya cerita sukses wirausahawan yang berkebutuhan khusus, berwirausaha terlalu berisiko, prosentase gagal memulai bisnis baru cukup besar, beratnya mengatur pemasukan dan pengeluaran, biaya memulai wirausaha cukup mahal, prosesnya rumit, menyita waktu, sulitnya mendapat bantuan atau bimbingan dari yang berwenang atau kompeten, serta pengawasan wirausaha cukup sulit.

Bila melihat manfaat wirausaha, maka ada optimistik bahwa anak berkebutuhan khusus mampu berwirausaha. Boylan \& Burchardt (2003:180) menyebutkan manfaat kegiatan tersebut, yaitu: adanya kemerdekaan dalam mengatur waktu kerja dan apa yang hendak dikerjakan, menciptakan peluang kerja bagi diri sendiri, menjadi bos, bisa kontak langsung dengan pelanggan, pemasok dan sebagainya, membuat hidup lebih bermakna, puas terhadap keberhasilan dan pribadi jika bisnis sukses, keamanan kerja tergantung pada diri sendiri bukan pada orang lain, adanya kemampuan untuk membuat keputusan bisnis. Selain manfaat perlu juga diantisipasi adanya kerugian, yaitu yang menjadi bos atau raja justru pelanggan, waktu bekerja fleksibel tetapi bisa menghabiskan waktu luang, pendapatan tidak stabil dan semua tanggung jawab dipikul oleh si wirausahawan tersebut (Boylan \& Burchardt, 2003:189).

Oleh karena itu, pendampingan wirausaha untuk para individu berkebutuhan khusus membutuhkan banyak bantuan dari berbagai pihak. Arnold, Seekins, \& Ravesloot (1995:10) mengemukakan bahwa sebenarnya banyak bidang yang bisa dijadikan wirausaha bagi individu berkebutuhan khusus sebagaimana ditunjukkan pada Tabel 1.

Arnold dkk (2003:52) memberikan rekomendasi langkah-langkah untuk membimbing kewirausahaan pada anak berkebutuhan khusus yang antara lain adalah sebagai berikut. (1) Individu mengekspresikan minat untuk berwirausaha. Ada individu yang sudah yakin untuk berwirausaha dan ada yang tidak. Individu yang masih ragu-ragu perlu diyakinkan bahwa berwirausahaan merupakan sebuah pilihan dan tujuan hidup. (2) Pembimbing dan individu membahas keuntungan dan kerugian dari wirausaha Pada 
Tabel 1. Bidang usaha bagi individu berkebutuhan khusus

\begin{tabular}{|c|c|c|}
\hline No. & Bidang & Bentuk Usaha \\
\hline 1. & Pertanian & $\begin{array}{l}\text { Petani, Bertanam organik, Penjual bibit tanaman/pupuk, petani ikan, Reparasi } \\
\text { alat pertanian, Beternak cacing/ulat sutra, Menanam jamur }\end{array}$ \\
\hline 2. & Pakaian & $\begin{array}{l}\text { pemilik toko pakaian, reparasi sepatu, penjahit, permak baju, } \\
\text { penjual pakaian bekas }\end{array}$ \\
\hline 3. & Hiburan & musisi, penyanyi profesional, penjual parabola, penjual alat musik \\
\hline 4. & $\begin{array}{l}\text { Hunting \& } \\
\text { Fishing }\end{array}$ & $\begin{array}{l}\text { pemilik toko alat-alat pancing, pembuat perahu, nelayan wisata, penjual ikan, } \\
\text { penjual makanan ikan, perbaikan mesin/perahu, penjual makanan dari ikan }\end{array}$ \\
\hline 5. & $\begin{array}{l}\text { Layanan } \\
\text { Profesional }\end{array}$ & arsitek, konselor, asuransi, penjual, agen real estate, desainer, pialang saham \\
\hline 6. & $\begin{array}{l}\text { Makanan \& } \\
\text { Minuman }\end{array}$ & $\begin{array}{l}\text { pembuat/penjual roti/kue, pemilik bar, juru masak, pemilik katering, } \\
\text { Koki/Chef, penjual minuman, pemilik restoran }\end{array}$ \\
\hline 7. & $\begin{array}{l}\text { Seni dan } \\
\text { Kerajinan }\end{array}$ & seniman, pengrajin, fotografer,pendongeng, penulis, pelukis, kartunis, komikus \\
\hline 8. & Otomotif & Pemilik bengkel, sales, mekanik \\
\hline 9. & Furniture & Reparasi furnitur, penyetem piano,pembuat perabotan \\
\hline 10. & Reparasi & $\begin{array}{l}\text { reparasi alat elektronik, reparasi jam, bengkel motor, reparasi AC,reparasi } \\
\text { mesin kecil/besar,tukang kunci }\end{array}$ \\
\hline 11. & Peternakan & Pemilik toko makanan binatang, penitipan hewan, salon hewan \\
\hline 12. & Building & $\begin{array}{l}\text { Desainer ruangan/interior, pemilik toko bangunan, kontraktor, tukang, renovasi } \\
\text { rumah, pelukis rumah, ahli saluran rumah, penjual/pemasang sistem keamanan } \\
\text { rumah }\end{array}$ \\
\hline 13. & Kesehatan, & $\begin{array}{l}\text { Petugas perawatan, pedicure/manicure, penjualan alat bantu dengar, terapi } \\
\text { pijat, terapis fisik, }\end{array}$ \\
\hline 14. & Perawatan & $\begin{array}{l}\text { Ahli kecantikan/salon/ kecantikan, tukang cukur,perawat/ } \\
\text { pengasuhanak,tukang cukur }\end{array}$ \\
\hline 15. & $\begin{array}{l}\text { Pelayanan } \\
\text { Publik }\end{array}$ & Akuntan, layanan telpon, pembukuan, operator komputer, penerjemah,pengetik \\
\hline 16. & Lain-lain & $\begin{array}{l}\text { Pembuat perhiasan, pemilik toko asesoris, pemilik toko sepeda dan asesoris, } \\
\text { pemilik tokoperlengkapan olah raga,sopir truk, penebang kayu, tukang kayu }\end{array}$ \\
\hline
\end{tabular}

langkah ini, pembimbing dan individu memulai dialog yang interaktif. Individu memberitahu ide bisnisnya dan pembimbing mengidentifikasi seberapa realistis individu mengusulkan bisnisnya. (3) Studi kelayakan, ada dua tahap yaitu mengembangkan ide menjadi lebih konkrit dengan merinci bisnis yang direncanakan, apa yang diproduksi, siapa konsumennya, biaya dan pendapatan yang diharapkan dari bisnis tersebut. Banyak yang memunyai rencana muluk sehingga ketika dihadapkan pada ide merealisasikan secara konkret mereka menjadi mundur dan merasa tidak mampu. Pembimbing perlu mengidentifikasi apakah perasaan tidak mampu karena kecacatan atau karena alasan lain, dan bantuan apa yang mereka butuhkan.

(4) Penilaian potensi Individu untuk berwirausaha, bagaimana kekuatan dan kelemahan dari karakter dan kepribadian indivividu sehingga dapat diperkuat dan dikembangkan melalui pelatihan atau pendampingan. (5) Identifikasi sumber untuk pelatihan, pendidikan, dan orang yang bisa membantu untuk mempersiapkan diri berwirausaha. Dimulai dengan mengidentifikasi pengetahuan dan keterampilan yang harus diraih individu untuk meningkatkan keberhasilan bisnisnya. Jasa, pendidikan, atau pelatihan dapat membantu individu mengembangkan rencana bisnis atau memperbaiki setiap kekurangan dalam keterampilan atau pengetahuannya. (6) Individu berhasil menyelesaikan pelayanan, pelatihan, atau pendidikan. Perlu dievaluasi apakah pelatihan atau pendidikan tersebut sesuai dengan kebutuhan dan apakah individu puas dengan kemampuan yang diperolehnya. Pada saat inilah kembali dievaluasi rencana bisnis awal, apakah individu masih tertarik untuk berwirausaha. Tekad ini perlu dilanjutkan ke arah yang makin kongkret. (7) Individu dan konselor bekerja dengan konsultan untuk mengembangkan rencana strategis, pemasaran, pendanaan dan sumber pendanaan. Pembimbing dan individu mengevaluasi semua 
draft rencana bisnis untuk memastikan lengkap dan menyeluruh terutama jika proposal bisnis diperlukan untuk mengajukan biaya ke lembaga yang mendanai (bank, lembaga kredit, pemerintah, dan sebagainya).

Untuk mengembangkan program kewirausahaan di sekolah bagi siswa berkebutuhan khusus, diperlukan data-data mengenai kebutuhan berwirausaha pada siswa berkebutuhan khusus tersebut. Oleh karena itu, penelitian ini berupaya untukmengidentifikasi kebutuhan berwirausaha pada siswa yang berkebutuhan khusus.

\section{METODE}

Penelitian menggunakan pendekatan kuantitatif deskriptif dengan metode survei. Subjek penelitian sebanyak 37 siswa berkebutuhan khususyang diambil dari 4 SLB di Yogyakarta. Pengambilan sampel dilakukan dengan teknik purposif, yaitu dengan mengambil subjek yang sudah berada di kelas lanjut (Kelas L) di SLB yang menjadi sampel. Pilihan pada kelas lanjut karena di kelas tersebut pembelajaran ditekankan pada keterampilan. Pilihan keterampilan disesuaikan dengan hasil asesmen. Profil subjek penelitian adalah umur penyandang kebutuhan khusus berada pada umur produktif, yaitu 17- 24 tahun dengan jumlah 29 orang, mayoritas pendidikan orang tua berada sekolah menengah atas, pekerja orang tua beragam mulai dari buruh sampai PNS. Orang tua yang berwirausaha ada 11 orang.

Metode pengumpulan data menggunakan kuestioner, wawancara, dan skala eksplorasi karier. Kuestioner digunakan untuk mengungkap kebutuhan berwirausaha, pilihan karier, pilihan pekerjaan, dan intense berwirausaha. Wawancara digunakan untuk mengungkap hambatan dalam mengambil keputusan bekerja. Skala eksplorasi karier digunakan untuk mengenal diri sendiri, pilihan minat, mengenal kemampuan diri, dan kebutuhan informasi karier. Analisis data menggunakan analisis deskriptif.

\section{HASIL PENELITIAN DAN PEMBAHASAN Hasil}

Analisis hasil penelitian mendeskripsikan (1) hasil analisis kebutuhan berwirausaha pada siswa berkebutuhan khusus, (2) hasil eksplorasi karir, dan (3) hasil identifikasi niat untuk berwirausaha.

\section{Hasil Analisis Kebutuhan Berwirausaha pada Siswa Berkebutuhan Khusus}

Para subjek penelitian dimintai untuk mengidentifikasi pilihan karirnya apakah merasa sudah mantap atau belum. Identifikasi pilihan karir mereka ditunjukan pada Tabel 2.

Pilihan pekerjaan subjek ditunjukkan pada Tabel 3.

Tabel 3. Pilihan Kerja

\begin{tabular}{|c|c|}
\hline \multicolumn{2}{|c|}{ Bagaimana Prioritas pilihan pekerjaan anda? } \\
\hline Tidak bekerja & 7 \\
\hline Bekerja diperusahaan / lembaga swasta & 18 \\
\hline Punya usaha sendiri & 12 \\
\hline Jumlah & 37 \\
\hline
\end{tabular}

Untuk prioritas pilihan kerja, 18 orang memilih bekerja di perusahaan/lembaga swasta, dan 12 siswa memilih berwirausaha. Pilihan profesi mereka ditunjukkan pada Tabel 4.

Pilihan kerja yang diinginkan siswa berkebutuhan kerja sangat beragam, mulai dari menjahit, memasak, bengkel, fotografi, komputer, salon sampai tukang pijat. Semua pilihan ini menuntut ketrampilan siswa berkebutuhan khusus, baik

\section{Tabel 2. Identifikasi Pilihan Karier}

\begin{tabular}{|c|c|c|c|}
\hline No. & Bagaimana Pilihan Pekerjaan Anda di masa depan? & Mantap & Belum Mantap \\
\hline 1. & Bekerja di perusahaan atau organisasi atau lembaga swasta & 1 & \\
\hline 2. & $\begin{array}{l}\text { Belum memutuskan tetapi punya } \\
\text { banyak pilihan }\end{array}$ & & 8 \\
\hline 3. & $\begin{array}{l}\text { Lihat kondisi situasi kerja setelah } \\
\text { lulus nanti }\end{array}$ & & 9 \\
\hline 4. & Ragu-ragu & & 6 \\
\hline 5. & Punya pilihan kerja & 9 & \\
\hline 6. & Terserah saja & & 3 \\
\hline 7. & Tidak punya pilihan pekerjaan & & 1 \\
\hline & To & 10 & 27 \\
\hline
\end{tabular}


Tabel 4. Pilihan Profesi

\begin{tabular}{ll}
\hline No. Kategori & Pilihan Profesi \\
\hline $\begin{array}{l}\text { 1. Bekerja } \\
\text { diperusahaan } \\
\text { atau organisasi } \\
\text { atau lembaga } \\
\text { swasta }\end{array}$ & $\begin{array}{l}\text { Garmen, Fotografi, Perbengkelan, Menjahit, Sepak bola, Guru SLB, PT } \\
\text { Bakpia, PT Rokok, PT Indovision, Salon dan Spa, PT Menjahit, PT } \\
\text { Indovision, Pimpinan, Pelukis, Karyawan, Bengkel, Pegawai bank, PNS, } \\
\text { Polisi, Seniman, Penyanyi, Dakwah }\end{array}$ \\
$\begin{array}{l}\text { Punya Usaha } \\
\text { Sendiri }\end{array}$ & $\begin{array}{l}\text { Menjahit, Menjual makanan, Pertanian, Cetak foto, Fotokopi, Fotografi, } \\
\text { Dagang, Dagang rumah makan(catering), Dagang Kue/roti, Pedagang } \\
\text { (perniagaan), Memasak, bidang computer, Loundry, Melukis, Buka toko }\end{array}$ \\
& $\begin{array}{l}\text { Pelukis, Berdagang, Dokter, Pimpinan, SalonKecantikan, Bengkel, Warung, } \\
\text { Menjahit, Restoran, Tukang pijat }\end{array}$ \\
\hline
\end{tabular}

Tabel 6. Hambatan Pengambilan Keputusan terkait Pekerjaan

\begin{tabular}{clc}
\hline No. & \multicolumn{1}{c}{ Hambatan } & Frekuensi \\
\hline 1. & Tidak mengenali kemampuan diri sendiri & 8 \\
2. & Kurangnya informasi mengenai lapangan kerja & 20 \\
3. & Tidak memunyai kemampuan yang memadai & 5 \\
4. & Belum memunyai gambaran pekerjaan yang akan dipilih & 7 \\
5. & Belum ada pekerjaan yang sesuai dengan cita-cita & 8 \\
6. & Tidak bisa mengambil keputusan & 9 \\
\hline
\end{tabular}

jika mereka bekerja sebagai karyawan maupun berusaha sendiri. Bila mereka berwirausaha maka keterampilan yang dibutuhkan tersebut misalnya: keterampilan bekerja sesuai bidang yang mereka pilih (menjahit, memasak atau reparasi bengkel) dan ketrampilan untuk mengelola usaha.

Dukungan orang tua terhadap pilihan karir anaknya ditunjukkan pada Tabel 5.

Tabel 5. Dukungan Orang Tua terhadap Pilihan Karir

\begin{tabular}{clcc}
\hline No. & Keluarga & Pilihan & Frekuensi \\
\hline 1. & Ayah & 1 & 21 \\
& & 2 & 4 \\
2. & Ibu & 1 & 8 \\
& & 2 & 16 \\
& & 3 & 1 \\
3. & Teman/Sahabat & 1 & 3 \\
4. & Guru & 2 & 3 \\
& & 3 & 5 \\
\hline
\end{tabular}

Hambatan subjek dalam hal pengambilan keputusan mengenai pekerjaan ditunjukkan pada Tabel 6.

Tiga hambatan terbesar yang dirasakan siswa berkebutuhan khusus adalah kurangnya informasi mengenai lapangan kerja, tidak bisa mengambil keputusan, dan tidak mengenali kemampuan diri.
Eksplorasi Karir Siswa Berkebutuhan Khusus

Dalam eksplorasi karir siswa berkebutuhan khusus ditemukan bahwa tingkat eksplorasi karier mereka seperti pada Tabel 8.

Tabel 8. Tingkat Eksplorasi karier anak berkebutuhan khusus

\begin{tabular}{lcccccrcr}
\hline & \multicolumn{2}{c}{ Rendah } & \multicolumn{2}{c}{ Sedang } & \multicolumn{2}{c}{ Tinggi } & \multicolumn{2}{c}{ Total } \\
& $\mathrm{F}$ & $\%$ & $\mathrm{~F}$ & $\%$ & $\mathrm{~F}$ & $\%$ & $\mathrm{~F}$ & \multicolumn{1}{c}{$\%$} \\
\hline Perempuan & 1 & 2,7 & 18 & 48,6 & 0 & 0 & 19 & 51,4 \\
Laki- laki & 2 & 5,4 & 15 & 40,5 & 1 & 2,7 & 18 & 48,6 \\
\hline Total & 3 & 8,1 & 33 & 89,2 & 1 & 2,7 & 37 & 100 \\
\hline
\end{tabular}

Secara keseluruhan dapat diketahui bahwa tingkat eksplorasi karir subjek penelitian adalah pada tingkat sedang.

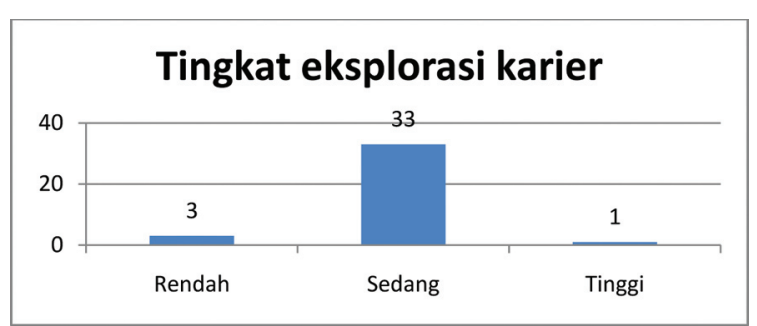

Grafik 1. Tingkat eksplorasi karir anak berkebutuhan khusus

Sebagian besar siswa sudah melakukan eksplorasi karir meskipun masih dalam tingkat 
sedang. Hanya 3 orang dari 37 siswa yang menjadi subjek penelitian iniyang tingkat eksplorasi karirnya rendah. Tetapi, hanya satu orang saja yang tingkat eksplorasi karirnya tinggi.

Bila dilihat dari jenis kelaminnya, sebaran tingkat eksplorasi karier mereka dapat dilihat di Grafik 2.

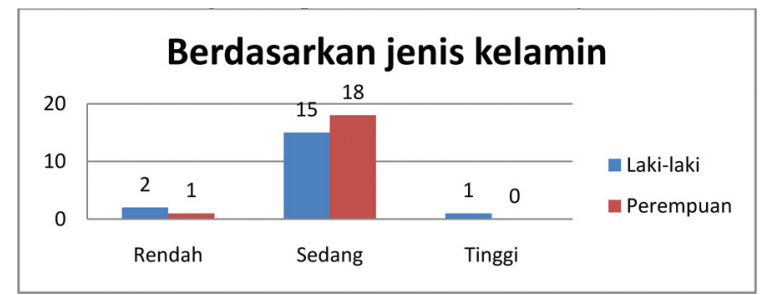

Grafik 2. Tingkat eksplorasi karier berdasar jenis kelamin

Jadi, tidak terdapat perbedaan yang mencolok antara siswa perempuan dan laki-laki dalam tingkat eksplorasi karir.
Indikator yang digunakan dalam eksplorasi karir adalah pengenalan diri, pilihan minat, pengenalan kemampuan diri, dan kebutuhan informasi. Data mengenai hal-hal tersebut ditunjukkan di bawah.

\section{Pengenalan Diri}

Dalam aspek ini diungkap bagaimana siswa memilih keterampilan, kegiatan ekstrakurikuler, bacaan yang sesuai, dan komunikasi dengan orangtuamengenai kewirausahaan.

Hasil terbanyak adalah bahwa siswa melakukan pengenalan diri melalui kisah sukses orang yang berwirausaha ( 34 orang) dan memilih keterampilanyang sesuai dengan cita-cita (34 orang).

Informasi pekerjaan yang paling dibutuhkan oleh siswa yang menjadi subyek penelitian ini adalah pertukangan sebanyak $86 \%$ dan kewirausahaan sebanyak $68 \%$.

Tabel 9a. Eksplorasi Karir Siswa Berkebutuhan Khusus: Pengenalan Diri

\begin{tabular}{|c|c|c|c|c|c|c|c|c|c|}
\hline \multirow{2}{*}{ No. } & \multirow{2}{*}{ Pengenalan Diri } & \multicolumn{2}{|c|}{ SS } & \multicolumn{2}{|c|}{$\mathbf{S}$} & \multicolumn{2}{|c|}{ TS } & \multicolumn{2}{|c|}{ STS } \\
\hline & & $\mathbf{F}$ & $\%$ & $\mathbf{F}$ & $\%$ & $\mathbf{F}$ & $\%$ & $\mathbf{F}$ & $\%$ \\
\hline 1. & $\begin{array}{l}\text { Saya ingin cepat bekerja setelah lulus SLB, } \\
\text { maka saya memilih keterampilan sesuai } \\
\text { cita-cita saya }\end{array}$ & 16 & 43 & 18 & 49 & 2 & 5 & - & - \\
\hline 2. & $\begin{array}{l}\text { Saya memahami minat saya, oleh karena itu } \\
\text { memilih kegiatan ekstra kurikuler sesuai } \\
\text { dengan minat saya }\end{array}$ & 2 & 6 & 9 & 24 & 23 & 62 & 3 & 8 \\
\hline 3. & $\begin{array}{l}\text { Saya memahami bakat saya, oleh karena itu } \\
\text { memilih bacaan pengisi waktu luang sesuai } \\
\text { dengan bakat saya. }\end{array}$ & 9 & 24 & 20 & 54 & 8 & 22 & - & - \\
\hline 4. & $\begin{array}{l}\text { Bekal inteligensi dan kemampuan yang saya } \\
\text { miliki mendukung untuk berwirausaha }\end{array}$ & 4 & 11 & 18 & 49 & 13 & 35 & 2 & 5 \\
\hline 5. & $\begin{array}{l}\text { Saya berdiskusi tentang kesuksesan atau } \\
\text { keberhasilan pekerjaan berwirausaha } \\
\text { dengan orang tua }\end{array}$ & 9 & 24 & 23 & 62 & 3 & 8 & 1 & 3 \\
\hline 6. & $\begin{array}{l}\text { Saya berusaha mencari kisah sukses orang } \\
\text { berwirausaha }\end{array}$ & 8 & 22 & 26 & 70 & 2 & 5 & 1 & 3 \\
\hline
\end{tabular}

Tabel 9b. Eksplorasi Karir Siswa Berkebutuhan Khusus: Pilihan Minat

\begin{tabular}{|c|c|c|c|c|c|c|c|c|c|}
\hline \multirow{2}{*}{ No. } & \multirow{2}{*}{ Pilihan Minat } & \multicolumn{2}{|c|}{ SS } & \multicolumn{2}{|c|}{$\mathbf{S}$} & \multicolumn{2}{|c|}{ TS } & \multicolumn{2}{|c|}{ STS } \\
\hline & & $\mathbf{F}$ & $\%$ & $\mathbf{F}$ & $\%$ & $\mathbf{F}$ & $\%$ & $\mathbf{F}$ & $\%$ \\
\hline 1. & Pembudidayaan lingkungan & 7 & 19 & 14 & 38 & 13 & 35 & 2 & 5 \\
\hline 2. & Teknisi, bengkel, laborat, peneliti & 2 & 6 & 9 & 24 & 23 & 62 & 3 & 8 \\
\hline 3. & Seni & 7 & 19 & 14 & 38 & 13 & 35 & 2 & 5 \\
\hline 4. & $\begin{array}{l}\text { Membantu orang lain (misal: guru, perawat, } \\
\text { kapster) }\end{array}$ & 4 & 11 & 13 & 35 & 12 & 32 & 7 & 19 \\
\hline 5. & Berdagang dan berwirausaha & 5 & 13 & 18 & 49 & 12 & 32 & 1 & 3 \\
\hline 6. & Sekretaris, pegawai bank, pegawai kantor & 3 & 8 & 6 & 16 & 23 & 62 & 5 & 14 \\
\hline
\end{tabular}


Tabel 9c. Eksplorasi Karir SBK: Pengenalan Kemampuan Diri

\begin{tabular}{|c|c|c|c|c|c|c|c|c|c|}
\hline \multirow{2}{*}{ No. } & \multirow{2}{*}{ Pengenalan Kemampuan Diri } & \multicolumn{2}{|c|}{ SS } & \multicolumn{2}{|c|}{$\mathbf{S}$} & \multicolumn{2}{|c|}{ TS } & \multicolumn{2}{|c|}{ STS } \\
\hline & & $\mathbf{F}$ & $\%$ & $\mathbf{F}$ & $\%$ & $\mathbf{F}$ & $\%$ & $\mathbf{F}$ & $\%$ \\
\hline 1. & $\begin{array}{l}\text { Saya mampu dalam bidang permesinan } \\
\text { dan pertukangan }\end{array}$ & 3 & 8 & 9 & 24 & 20 & 54 & 5 & 14 \\
\hline 2. & $\begin{array}{l}\text { Saya mampu dalam bidang ketelitian dan } \\
\text { hitung-menghitung }\end{array}$ & 2 & 5 & 15 & 41 & 16 & 43 & 3 & 8 \\
\hline 3. & $\begin{array}{l}\text { Saya mampu dalam bidang kewirausahaan } \\
\text { (sales, berdagang, punya usaha sendiri) }\end{array}$ & 1 & 3 & 19 & 51 & 13 & 35 & 4 & 11 \\
\hline 4. & $\begin{array}{l}\text { Saya mampu dalam bidang karang- } \\
\text { mengarang, menyusun berita, dan tulis- } \\
\text { menulis }\end{array}$ & 6 & 16 & 10 & 27 & 17 & 46 & 3 & 8 \\
\hline
\end{tabular}

Tabel 9d. Eksplorasi Karir SBK: Kebutuhan Informasi

\begin{tabular}{|c|c|c|c|c|c|c|c|c|c|}
\hline \multirow{2}{*}{ No. } & \multirow{2}{*}{ Kebutuhan Informasi } & \multicolumn{2}{|c|}{ SS } & \multicolumn{2}{|c|}{$\mathbf{S}$} & \multicolumn{2}{|c|}{ TS } & \multicolumn{2}{|c|}{ STS } \\
\hline & & $\mathbf{F}$ & $\%$ & $\mathbf{F}$ & $\%$ & $\mathbf{F}$ & $\%$ & $\mathbf{F}$ & $\%$ \\
\hline 1. & Informasi tentang pekerjaan peternak & 3 & 8 & 11 & 30 & 18 & 49 & 5 & 13 \\
\hline 2. & $\begin{array}{l}\text { Informasi tentang pekerjaan pertanian dan } \\
\text { perkebunan }\end{array}$ & 5 & 13 & 10 & 27 & 18 & 49 & 4 & 11 \\
\hline 3. & $\begin{array}{l}\text { Informasi tentang pekerjaan pelayaran dan } \\
\text { kelautan }\end{array}$ & 3 & 8 & 11 & 30 & 18 & 49 & 5 & 13 \\
\hline 4. & Informasi tentang pekerjaan pertukangan & 9 & 24 & 22 & 60 & 6 & 16 & & \\
\hline 5. & Informasi tentang pekerjaan perbengkelan & 4 & 11 & 7 & 19 & 16 & 43 & 8 & 22 \\
\hline 6. & $\begin{array}{l}\text { Informasi tentang pekerjaan teknisi } \\
\text { (komputer) }\end{array}$ & 6 & 16 & 17 & 46 & 9 & 24 & 3 & 8 \\
\hline 7. & Informasi tentang pekerjaan penyanyi & 2 & 5 & 3 & 8 & 23 & 62 & 8 & 22 \\
\hline 8. & Informasi pekerjaan pemusik & 2 & 5 & 4 & 11 & 9 & 24 & 22 & 60 \\
\hline 9. & $\begin{array}{l}\text { Informasi tentang pekerjaan pelukis, } \\
\text { dekorator }\end{array}$ & 3 & 8 & 13 & 35 & 14 & 38 & 7 & 19 \\
\hline 10. & $\begin{array}{l}\text { Informasi tentang pekerjaan penata rambut, } \\
\text { kapster, dan kecantikan }\end{array}$ & 4 & 11 & 13 & 35 & 13 & 35 & 7 & 19 \\
\hline 11. & Informasi tentang pekerjaan guru & 3 & 8 & 7 & 19 & 20 & 54 & 7 & 19 \\
\hline 12. & $\begin{array}{l}\text { Informasi tentang pekerjaan perawat, } \\
\text { dokter }\end{array}$ & & & 6 & 16 & 21 & 57 & 9 & 24 \\
\hline 13. & $\begin{array}{l}\text { Informasi tentang pekerjaan konselor (guru } \\
\text { BP), psikolog }\end{array}$ & 1 & 3 & 4 & 11 & 22 & 59 & 10 & 27 \\
\hline 14. & $\begin{array}{l}\text { Informasi tentang pekerjaan sales, } \\
\text { pedagang (perniagaan) }\end{array}$ & 4 & 11 & 7 & 19 & 20 & 54 & 6 & 16 \\
\hline 15. & $\begin{array}{l}\text { Informasi tentang pekerjaan pemandu } \\
\text { wisata untuk turis }\end{array}$ & 4 & 11 & 5 & 14 & 19 & 51 & 9 & 24 \\
\hline 16. & Informasi tentang pekerjaan kewirausahaan & 3 & 8 & 22 & 60 & 10 & 27 & 2 & 5 \\
\hline 17. & Informasi tentang pekerjaan kesekretariatan & 1 & 3 & 12 & 32 & 14 & 38 & 10 & 27 \\
\hline 18. & $\begin{array}{l}\text { Informasi tentang pekerjaan kantor } \\
\text { (ketatausahaan) }\end{array}$ & 2 & 5 & 11 & 30 & 15 & 40 & 8 & 22 \\
\hline 19. & Informasi tentang pekerjaan pegawai bank & 5 & 13 & 8 & 22 & 16 & 43 & 8 & 22 \\
\hline
\end{tabular}

\section{Niat untuk Berwirausaha}

Niat siswa berkebutuhan khususuntuk berwirausaha terlihat seperti pada Tabel 10.

Tabel 10.Niat/Intensi berwirausaha siswa berkebutuhan khusus

\begin{tabular}{lllrrrrrr}
\hline & \multicolumn{2}{c}{ Rendah } & \multicolumn{2}{c}{ Sedang } & \multicolumn{2}{c}{ Tinggi } & \multicolumn{2}{c}{ Total } \\
\cline { 2 - 9 } & $\mathrm{F}$ & $\%$ & $\mathrm{~F}$ & $\%$ & $\mathrm{~F}$ & $\%$ & $\mathrm{~F}$ & $\%$ \\
\hline Perempuan & 0 & 0 & 7 & 18 & 11 & 30 & 18 & 48 \\
Laki- laki & 4 & 11 & 4 & 11 & 11 & 30 & 19 & 52 \\
Total & 4 & 11 & 11 & 30 & 22 & 60 & 37 & 100 \\
\hline
\end{tabular}

Secara keseluruhan dapat diketahui bahwa tingkat intensitas atau niat siswa berkebutuhan khusus untuk berwirausaha adalah tinggi.

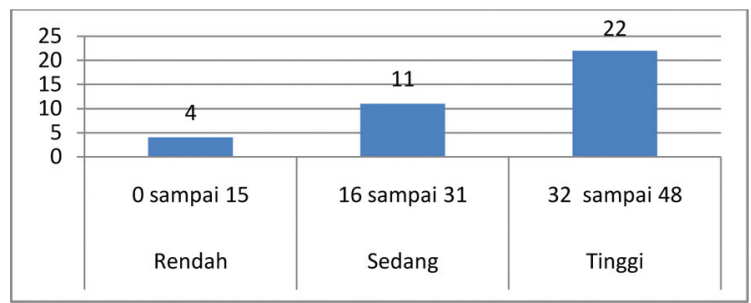

Grafik 3. Tingkat intensitas KWU 
Pada siswa perempuan, tidak ada yang memiliki intensitas kewirausahaan yang rendah, berbeda dengan siswa laki-laki ada 4 orang yang rendah intensitasnya.

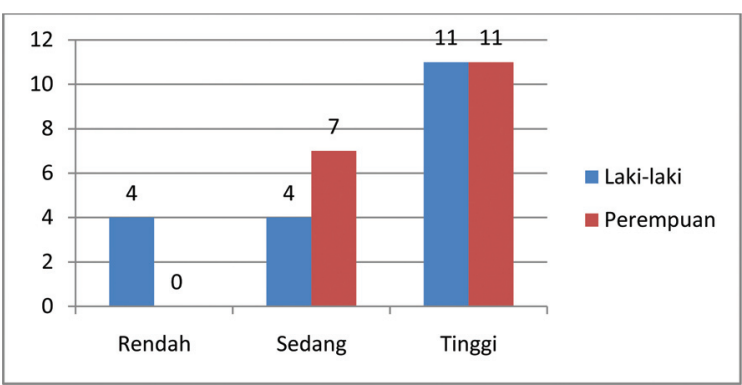

Grafik 4. Tingkat intensitas KWU berdasar jenis kelamin

Selain itu, tidak ada perbedaan intensitas kewirausahaan yang mencolok antara siswa lakilaki dan perempuan, jumlahnya sama pada tingkat intensitas yang tinggi bahkan pada tingkat intensitas yang sedang lebih banyak siswa perempuan daripada siswa laki-laki. Artinya siswa perempuan memiliki tingkat intensitas kewirausahaan yang bagus.

Dari keseluruhan pernyataan mengenai niat atau intensi berwirausaha, dapat dikatakan intensi siswa berkebutuhan khusus untuk berwirausaha masih berada pada tingkat sedang dengan intensi yang paling tinggi berada pada pernyataan" Saya memiliki niat yang kuat untuk memulai usaha sendiri suatu saat nanti" sebanyak 26 orang (70 $\%$ ) dan "Saya mencari informasi untuk memulai dan menjalankan usaha saya sendiri" sebanyak 24 orang $(65 \%)$.

\section{Pembahasan}

Dari hasil penelitian dapat diketahui bahwa berwirausaha merupakan salah satu pilihan dan prioritas kerja bagi siswa berkebutuhan khusus. Artinya, siswa sudah mulai menyadari bahwa berwirausaha merupakan peluang karir di masa depan yang harus disiapkan sejak dini. Menurut siswa, bidang-bidang yang bisa dijadikan lahan berwirausaha cukup beragam yaitu: memasak, menjahit, pijat, melukis, dan sebagainya, tapi bidang bidang ini membutuhkan ketrampilan individual di mana tidak setiap sekolah mampu memberikan ketrampilan sesua dengan cita-cita anak. Tiga hambatan terbesar yang dirasakan siswa berkebutuhan khusus adalah kurangnya informasi mengenai lapangan kerja, tidak bisa mengambil keputusan, dan tidak mengenali ke- mampuan diri. Artinya, menurut Arnold (2011), jika sudah ada minat untuk berwirausaha, maka hal yang harus dilakukan adalah memantapkan keyakinan siswa untuk berwirausaha, mengidentifikasi bidang usaha berdasarkan minat, kelayakan, dan untung rugi usaha serta menguatkan potensi diri untuk berwirausaha.

Orang yang dianggap berpengaruh dalam mendukung pilihan karir mereka adalah orangtua, yaitu ayah dan ibu. Namun, untuk anak berkebutuhan khusus guru menempati pilihan pertama, setelah ayah dan ibu.Orang atau individu yang membantu dalam perencanaan karier adalah berturut-turut dari ranking tertinggi adalah orangtua, tokoh karier, guru, wali kelas. Sehingga perlu menyadarkan orangtua bahwa siswa berkebutuhan khusus juga ingin mandiri termasuk dalam bekerja karena bekerja tidak hanya terkait dengan mengumpulkan uang atau mendapatkan penghasilan tetapi juga merupakan bentuk eksistensi diri dan upaya mereka untuk beradaptasi dengan lingkungan sosial (Rokhim \& Handoyo, 2015:6). Peran orangtua dalam fasilitasi karier adalah berusaha memfasilitasi dan menjadikan model bagi anak mereka dalam pilihan karier anak. Selain itu, orangtua bisa menyediakan modal, peralatan, transportasi serta bantuan psikologis untuk mendampingi anaknya dalam berproses untuk menjadi wirausahawan (Boylan \& Burchardt, 2003:69), hal ini yang tentu saja tidak bisa dilakukan secara maksimal oleh guru karena keterbatasan waktu, dana dan kemampuannya.

Tingkat eksplorasi karir subyek penelitian adalah pada tingkat sedang dan tidak terdapat perbedaan yang menyolok antara siswa perempuan dan laki-laki dalam tingkat eksplorasi karir. Sebagian besar merasa mampu dalam bidang kewirausahaan (sales, berdagang, punya usaha sendiri) yaitu sebanyak $54 \%$. tingkat intensitas atau niat siswa berkebutuhan khusus untuk berwirausaha adalah tinggi. Eksplorasi karir siswa masih bisa dikembangkan dan ditingkatkan karena bidang-bidang untuk berwirausaha masih sangat luas (Arnold, Seekins, \& Ravesloot, 1995:16). Intensitas kewirausahaan subjek berada pada tingkat yang tinggi bahkan siswa perempuan memiliki tingkat intensitas kewirausahaan yang bagus daripada siswa laki-laki. Jika sekolah memunyai fasilitas yang terbatas, maka siswa berkebutuhan khusus hendaknya diberi kemampuan untuk mengakses internet sehingga informasi peluang usaha yang mereka butuhkan dapat dicari melalui 
dunia maya (Kitching, 2014:65) sebagaimana yang diungkapkan siswa bahwa mereka membutuhkan informasi sebanyak-banyaknya mengenai usaha yang bisa mereka kembangkan.

\section{PENUTUP}

Dapat disimpulkan bahwa tingkat intensitas siswa berkebutuhan khusus untuk berwirausaha tinggi tapi esplorasi karir masih berada pada tingkat sedang. Hal ini disebabkan karena hambatan internal dan eksternal yang dihadapi siswa yaitu: kurangnya informasi mengenai lapangan kerja, tidak bisa mengambil keputusan, dan tidak mengenali kemampuan diri. Artinya bantuan yang dibutuhkan siswa adalah kebutuhan informasi serta pengenalan dan pengembangan potensi diri untuk berwirausaha. Selain itu, siswa juga membutuhkan model atau contoh dari penyandang kebutuhan khusus yang sukses menjalankan wirausaha.

\section{UCAPAN TERIMA KASIH}

Penulis mengucapkan terima kasih kepada para Guru SLB yang telah membantu penelitian terutama dalam memberikan masukan draf buku panduan yang akan diimplementasi dalam penelitian ini. Penulis juga mengucapkan terima kasih kepada Redaksi dan Staff Jurnal Cakrawala Pendidikan yang telah memberikan kesempatan untuk mempublikasikan artikel hasil penelitian ini.

\section{DAFTAR PUSTAKA}

Arnold, N., Seekins, T., Ipsen, C., \& Colling, K. 2003. "Self-employment for people with Disabilities in the United States: A Recommended Process for Vocational Rehabilitation Agencies". Australian Journal of Career Development, 12(1), 49-57.

Arnold, N. L., Seekins, T., \& Ravesloot, C. 1995. "Self-employment as a Vocational Rehabilitation Employment Outcome in Rural and Urban Areas" Montana, 2, 5-17.
Boylan, A., \& Burchardt, T. 2003. Barriers to Self-employment for Disabled People. SBS Research \& Evaluation.

Caliendo, M., Fossen, F., \& Kritikos, A. S. 2014. "Personality Characteristics and the Decisions to Become and Stay Self-Employed". Small Business Economics, 42(4), 787 814.

Gilkerson, L. D., \& Paauwe, T. M. 2003. Selfemployment: from Dream to Reality: an Interactive Workbook for Starting Your Small Business. JIST Works.

Kementerian Kesehatan, R. I. 2012. "Buletin Jendela Data dan Informasi Kesehatan: Situasi Penyandang Disabilitas". Jakarta: Kementerian Kesehatan RI.

Kitching, John. 2014. Entrepreneurship and Self-Employment by People with Disabilities. (Project Report) Paris, France : Organisation for Economic Co-operation and Development. 25 p. $63-67$

Kiyosaki, R. T., \& Lechter, S. L. 2001. The cashflow Quadrant: Panduan Ayah Kaya Menuju Kebebasan Finansial. Jakarta: Gramedia Pustaka Utama.

Rokhim, F., \& Handoyo, P. 2015. "Makna Kerja bagi Penyandang Disabilitas di Yayasan Bina Karya "Tiara Handycraft" Surabaya. Paradigma, 3(03), 1-9.

Syamsi, I. 2010. "Membuka Peluang Berwirausaha untuk Pemberdayaan Anak Berkebutuhan Khusus".Jurnal Pendidikan dan Kebudayaan Dikbud. 16 (1). 90-103

Winasti, M. 2012. "Motivasi Berwirausaha Pada Penyandang Disabilitas Fisik". Empathy Jurnal Fakultas Psikologi, 1(1), 177-187. 